\title{
NUTRITIONAL EVALUATION OF THE PRINCIPAL FORAGES / FEED CONSUMED BY INDIAN RHINO (RHINOCEROS UNICORNIS) IN POBITORA WILDLIFE SANCTUARY AND ASSAM STATE ZOO-CUM-BOTANICAL GARDEN, ASSAM
}

\author{
R.J. Deka ${ }^{1}$, N.K. Sarma ${ }^{2}$ and K.K. Baruah ${ }^{3}$ \\ ${ }^{1}$ M.V.Sc. student, ${ }^{2}$ Associate Professor, Department of A.P.M., ${ }^{3}$ Professor, \\ Department of Animal Nutrition, College of Veterinary Science, Assam Agricultural University, Assam, India.
}

\begin{abstract}
Rhinos in Pobitora Wildlife Sanctuary principally feed on 22 species of grasses and plants, considering the seasonal variation on the availability of food sources. The proximate analysis of food revealed that they contain moisture (80-85\%), crude protein (6-15\%) and ash (1015\%). The rhinos in Assam State Zoo-cum-Botanical Garden are being maintained on a daily ration of green grasses $(100 \mathrm{~kg})$, concentrate feed $(7 \mathrm{~kg})$ and monthly supplements of minerals $(500 \mathrm{~g})$. The chemical analysis of grass and feed mixture revealed that they contain moisture $11-80 \%$, crude protein $7-18 \%$ and ash $5-14 \%$.
\end{abstract}

\section{Keywords}

Indian rhino, nutritional evaluation, grasses, feed mixture, Pobitora WIldlife Sanctuary, Assam State Zoo-cum-Botanical Garden

\section{Introduction}

Studies on the feeding habits of Indian Rhinocerous Rhinoceros unicornis have shown that it is completely herbivorous (Grzimek, 1970; Laurie, 1978; Patar, 1980). Short and tall grasses, shrubs, herbs, leaves, twigs, aquatic plants and occasionally fruits make the principal diet of the species.

At present, Assam houses the world's largest surviving population of R. unicornis, which is threatened globally. During the last seven decades the Indian Rhino population showed a (hopefully) increasing trend, however, their area of occupancy dwindled in size. Although, the population of $R$. unicornis is highest in Assam, little efforts have been made to know about their feeding habits. Therefore, some baseline study on its feeding habits was considered essential.
The study on the nutritional composition of the principal forages of $R$. unicornis can provide an insight into the physiology of the species as well as help us in assessing the habitat. It will also be helpful in developing feeding strategies and optimal diets for the managed population.

\section{Study area}

Pobitora Wildlife Sanctuary is located in the flood plains of river Brahmaputra. The area of Pobitora Wildlife Sanctuary falls within $26^{\circ} 12^{\prime} \mathrm{N}$ to $26^{\circ} 15^{\prime} \mathrm{N}$ and $92^{\circ} 2^{\prime} \mathrm{E}$ to $92^{\circ} 5^{\prime} \mathrm{E}$. The area of the Sanctuary is flat with gentle east to west inclination excluding Burh Mayong Hillock. The vegetation of the Sanctuary is classified into four distinguished forest types as per Champion and Seth (1968) -eastern west alluvial grassland (1/4/4d/2S), Barriuglonia swamp forest (1/4/4d/5S), low alluvial savannah (Salmania albizzia) woodland (1/3/1S) and northern moist mixed deciduous forest (Burha Mayong Hillock) (1/3/3C/C/2S). According to the census report in 1999, there are 74 rhinos in Pobitora Wildlife Sanctuary in an area of only $16 \mathrm{~km}^{2}$ with the highest density of Greater Onehorned Rhinoceros population.

The Assam State Zoo-cum-Botanical Garden situated in the heart of Guwahati City, is at present maintaining eight Indian Rhinos. The study was done on two adult males bearing International Studbook No. IS-173 and IS-174.

\section{Methodology}

Sources of data: The feed / forage samples were collected from Pobitora Wildlife Sanctuary, Assam in natural condition and from Assam State Zoo-cum-Botanical Garden in July 2001.

Collection of samples: Different forages from natural pasture consumed by animals during grazing was observed. Some short term observations were made by following rhinos as far as 
possible to survey the varieties of plants they consumed. Plants fed by the rhinos were collected from places where they spent more than 10 minutes, usually of plants that had saliva or were torn on the top. The grasses were identified with the help of a taxonomist and botanical names were recorded.

In captivity, samples were collected from the offered feed mixtures and grasses. The proximate analysis of the collected samples was done according to AOAC (1990).

\section{Results}

The Indian Rhinos are generally grazers and occassional browsers. Their forages in Pobitora Wildlife Sanctuary are grasses, shrubs, tree leaves, aquatic plants and sometime fruits. The different species of plants that constitute the diet of $R$. unicornis are given in Table 1. During the observation it was found that rhinos mostly feed on 22 species of plants. Grasses comprise the major part of the total plants eaten. Out of the 22

Table 1. Principal and most preferred food plants of R. unicornis in Pobitora Wildlife Sanctuary with the local names

\begin{tabular}{|c|c|}
\hline Localname & Botanical name \\
\hline \multicolumn{2}{|l|}{ Grasses } \\
\hline$\overline{\text { Birina* }^{*}}$ & Vetiveria zizanodes (L.) Wash. \\
\hline Khagori* & Saccharum spontaneum \\
\hline Ekora* & Selerostachya fusca (Roxb.) Ridley \\
\hline $\mathrm{Na}{ }^{*}$ & Phragmitis karka (Retz.) Trin. \\
\hline Bamdal* & Andropogon spp. \\
\hline Locusa* & Hemarthia compresa \\
\hline$D a l^{*}$ & Hymenachae amplexicaolis \\
\hline Arali* & Leersia hexandra Sw. \\
\hline Dub grass* & Cynodon dactylon (L.)Pers. \\
\hline Keyaban & Cyperous rotundus \\
\hline Barkeyaban & Eleusina indica (L.) Gaerth \\
\hline Hogol* & Notidentified \\
\hline Ulu ban* & Imperata cylindrical (L.) P. Beauv. \\
\hline Sonkher & Pallinia cilata \\
\hline Kathia & Oryza sativa (seedling) \\
\hline \multicolumn{2}{|l|}{ Aquatic plants } \\
\hline$\overline{\text { Meteka }}$ & Eichhornia crassipes \\
\hline Kalmou & Ipomea reptans \\
\hline Helonchi & Enhydraflucluans \\
\hline \multicolumn{2}{|l|}{ Treesaplings } \\
\hline \multicolumn{2}{|l|}{ Era } \\
\hline \multicolumn{2}{|l|}{ Dimoru } \\
\hline \multicolumn{2}{|l|}{ Ghunsaplant } \\
\hline \multicolumn{2}{|c|}{ Fruits } \\
\hline Kata Bengena & Solanum carotinense \\
\hline
\end{tabular}

*most preferred plants species of plants, 11 species of grasses were recorded to be the most preferred food sources of the Indian Rhinos (Table 1). The chemical analysis of these grasses revealed that they contain $80-85 \%$ moisture, $6-15 \%$ crude protein $(\mathrm{CP})$ and $10-15 \%$ ash (Table 3).

Rhinos in captivity were truly based on the offered feed mixture and grasses for their feeding. The animals were provided with green grass and feed mixture twice daily and 500g black salt was given monthly. The different food items available for $R$. unicornis in Assam State Zoo are:

a) Grasses: Hymenachae amplexicaolis, Brachiaria mitica, Kyllinga brevifolia*, Cynodon dactylon*

(*available in the enclosure)

b) Concentrate feed mixture: Gram, black gram, wheat bran

c) Fruits/vegetables: Banana, cabbage etc.

d) Minerals: Common salt, commercial mineral salt.

The daily ration for $R$. unicornis at the zoo was computed as follows:
1. Green grass

2. Concentrate feed

3. Banana

4. Vegetables

5. Common salt

6. Mineral mixture
$100 \mathrm{~kg}$ $6 \mathrm{~kg}$ (gram $2 \mathrm{~kg}$, black gram $2 \mathrm{~kg}$, wheat bran $2 \mathrm{~kg}$ ) 8-10nos.

$2 \mathrm{~kg}$

$20 \mathrm{~g}$

$500 \mathrm{~g}$
The proximate analysis revealed that grasses contain $79-82 \%$ moisture, $7-9 \%$ protein and $10-11 \%$ ash, and the feed mixture contain $11-80 \%$ moisture, $14-18 \% \mathrm{CP}$ and $5-24 \%$ ash. These are given in Table 4.

\section{Discussion}

The sources of food items of $R$. unicornis were studied in natural condition in Pobitora Wildlife Sanctuary. It was clear from the study that the food items of $R$. unicornis were green grasses and plants. Similar observations were also reported by Grzimek (1970), Laurie (1978), Patar (1980) and Bhattacharya (1991). $R$. unicornis was found to consume long grasses like Vetiveria zizanoides, Saccharum spp., Pharagmitis karka, Selerostachya fusca, Hymenachane spp., short grasses like Hemerthia compressa, Leersia hexandra, Pollinia cilata etc., aquatic plants like Hogol, Water hyacinth, Ipomea spp., Helochi etc., tree saplings of Dimoru, Ghunsa and fruits of Solanum carotinense. These findings were in congruence with the findings of Laurie (1978) in Nepal, Bhattacharya (1991) and Mary et al. (1998) in Kaziranga National Park. These workers also reported the abundance of the same which are found in Pobitora Wildlife Sanctuary, although they have conducted their study in Royal Chitawan National Park, Nepal and Kaziranga National Park. 
Table 3. Chemical compositions of preference status of food plants of R. unicornis in Pobitora Wildlife Sanctuary (in percentage).

\begin{tabular}{llllll}
\hline Local name & Botanical name & DM & Moisture & CP & Ash \\
\hline Birina & Vetiveria zizanodes & 19.1 & 80.9 & 6.7 & 15 \\
Khagori & Saccharum spontaneum & 19.5 & 80.5 & 6.82 & 11.2 \\
Ekora & Selerostachyafusca & 15.5 & 84.5 & 6.2 & 12.7 \\
Nal & Phragmitis Karka. & 15 & 85 & 6.3 & 11.8 \\
Bam dal & Andropogon spp. Hemarthiacompresa & 18 & 82 & 6.55 & 9.2 \\
Locusa & Hymenachae amplexicaolis & 17 & 83 & 6.33 & 12.3 \\
Dal & Leersiahexandra & 15.8 & 84.2 & 6.5 & 10.33 \\
Arali & Cynoconn dactylon & 18.9 & 81.1 & 7.1 & 11.9 \\
Dubgrass & Notidentified & 16 & 84 & 15.2 & 12 \\
Hogol & Imperatacylindrical. & 17 & 83 & 6.2 & 11 \\
Uluban & & 19 & 81 & 5.5 & 8.2 \\
\hline
\end{tabular}

The samples collected during the study in natural conditions were found to contain 80-85\% moisture, 6-15\% CP and 10-15\% ash. However, Ranjhan (1991) stated in his publications that these grasses contain $72-84 \%$ moisture, $4-22 \% \mathrm{CP}$ and $10-17 \%$ ash. These variations might be due to soil type and other ecological factors.

The rhinos in captivity have been maintained on a daily ration of green grass $(100 \mathrm{~kg})$, concentrate feeds $(7 \mathrm{~kg})$ and monthly supply of minerals (500g) for licking. Crandall (1964), Grzimek (1970) observed this type of rationing in different zoos and Bhattacharya (1991) also observed such rationing in Assam State Zoo cum Botanical Garden. The chemical analysis of grass that are offered to captive Rhinos is similar to that reported by Ranjhan (1991).

\section{Acknowledgement}

The authors are immensely indebted to Sri S. Doley, C.C.F. (Wildlife), Govt. of Assam for his kind permission to carry out the study in Pobitora Wildlife Sanctuary and Assam State Zoo cum Botanical Garden, Guwahati, Assam. The authors also bear immense pleasure to conveying their profound sense of gratitude to the D.F.O., Assam State Zoo and the Range Officer, Pobitora Wildlife Sanctuary.

\section{References}

Bhattacharya, B.K. (1991). Studies on Certain Aspect of Biology on R. unicornis. Ph.D. thesis, Guwahati University, (unpublished)..

Crandall, L.S. (1964). The Management of Wild Animals in Captivity, Fourth Impression, 1971, Printed in the U.S.A., University of Chicago. Grazimek, H.C.B. (1970). Animal Life Encyclopedia Vol. IV, Von Nostrund Reinhold Co., New York.

Laurie, W.A. (1978). The ecology and behaviour of the Greater One Horned Rhinoceros. Ph.D. dissertation, University of Cambridge, (unpublished)..

Mary, P.P., G.S. Solanki, D. Limbo and K. Upadhay (1998). Observation on feeding and territorial behaviour of Indian Rhino $(R$. unicornis) in Kaziranga National Park, Assam, India. Tigerpaper 25(4): 25-28.

Patar, K.C. (1980). Some observations on the behaviour of One-horned Rhinoceros in Kaziranga National Park development without destruction. Paper presented in a Seminar organized by Department of Forest, Meghalaya (unpublished).

Ranjhan, S.K. (1991). Chemical Composition and Nutritive Value of Indian Feeds and Feeding of Farm Animals, ICAR Publication, New Delhi.

Table 4. Chemical compositions of different types of feeds / forages offered to R. unicornis in captivity (in percentage)

\begin{tabular}{|c|c|c|c|c|c|}
\hline Local name & Botanical name & DM & Moisture & $\mathrm{CP}$ & Ash \\
\hline \multicolumn{6}{|l|}{ Grasses } \\
\hline$\overline{D a l}$ & Hymenachae amplexicaolis & 20.9 & 79.1 & 7.1 & 11.9 \\
\hline Para & Brachiaria mutica & 18 & 82 & 9 & 10.3 \\
\hline \multicolumn{6}{|l|}{ Feed mixture } \\
\hline Wheatbran & - & 88.9 & 11.1 & 14.7 & - \\
\hline Black gram & Phaseolus mungo & 100 & - & 15 & 5.1 \\
\hline Cabbage & Brasscia oleracea & 20 & 80 & 18 & 24.2 \\
\hline
\end{tabular}

